\title{
Raw Salmon- and Seafood-Associated Infection
}

\author{
Attapon Cheepsattayakorn ${ }^{1 *}$ and Ruangrong Cheepsattayakorn ${ }^{2}$ \\ ${ }^{1} 10^{\text {th }}$ Zonal Tuberculosis and Chest Disease Center, Chiang Mai, Thailand \\ ${ }^{2}$ Department of Pathology, Faculty of Medicine, Chiang Mai University, Chiang Mai, \\ Thailand \\ *Corresponding Author: Attapon Cheepsattayakorn, $10^{\text {th }}$ Zonal Tuberculosis and \\ Chest Disease Center, Chiang Mai, Thailand.
}

DOI: $10.31080 /$ ASMI.2020.03.0517

Salmon and other seafoods (mollusks, finfish, marine mammals, fish eggs, and crustaceans), nutrient-rich parts of healthy diets. Nevertheless, the potential risks of eating contaminated seafoods can come along with the benefits and nutrients derived from seafood consumption. Infectious agents (Vibrio species, Salmonella, Shigella species, Clostridium botulinum, other toxin-forming bacteria, Norovirus, Hepatitis A virus, Helminths (nematodes, trematodes, and cestodes (Diphylobothrium species, members of the family Anisakidae, and eustrongyloides)), protozoa (Giardia species), metals, marine toxins, and chemicals have been identified in seafoods. In the United States, seafood-related outbreaks of infection vary by seafood commodity that mollusk, fish, and crustaceans are estimated $45.2 \%, 38.8 \%$, and $16.0 \%$ of outbreaks, respectively.

In the mid-19th century, Japanese broad-tapeworm infection, such as Diphyllobothrium nihonkaiense and D latum was known to be contracted by eating raw salmon (Oncorhynchus masou, 0 gorbuscha, and $O$ keta). In Japan, from 1988 to 2008, a total of 149 cases of diphyllobothriasis, particularly $D$ nihonkaiense have been identified by deoxyribonucleic acid (DNA) sequencing of the tapeworm cox1 and/or nad3 genes. These cases had a history of eating raw salmon or a habit of eating suchi or sashimi, which are normally composed of seafish, often salmon. Previous molecular studies of DNA sequences of the 18S rDNA, internal transcribed region 1, cox1 and nad3, definitely demonstrated the synonym of D klebanovskii to D nihonkaiense, revealed that D nihonkaiense is distributed in Japan, Far East Russia, and the Kamchatka Peninsula that brown bears are its natural final host, in addition to outbreaks of Diphyllobothrium infection related to raw salmon consumption in the United States and case reports of this parasitic infection related to raw salmon eating in South Korea.

Pathogenic contamination in seafood with human reservoirs can occur when growing areas are contaminated with human sewage. Identified seafood-contamination sources include overboard sewage discharge into harvested areas, sewage runoff from points inland after heavy rains or flooding, and illegal harvesting from sewage-contaminated waters, in addition to seafood contamination during preparation, processing, and handling. Storage and transportation at unsuitable temperatures, cross-contamination through contact with contaminated seafood or seawater may be contributing factors. Unlike other foods that are usually cooked, seafood is often consumed raw or preparing ways that do not totally kill organisms.

Risk mitigating factors include: 1) Freezing has been used to kill parasites in the seafood industry, particularly raw and uncooked fish, 2) Good Aquaculture Practices (GAPs) in farmed fish have potential to reduce and eliminate the pathogenic loads in farmed fish, 3) Selective harvesting of younger fish among species where parasites accumulate during the life of fish, 4) Fishing outside marine mammal areas because fish from near-shore waters frequented by marine mammals often demonstrate a larger number of parasites, 5) Rapid chilling and gutting following harvest to prevent worms from migrating from the viscera, where they mainly accumulate into the flesh which is consumed, 6) Trimming away the belly flaps of fish and physically removing the parasites, 7) Candling, a process by which the fish fillet is placed on a light table and parasites are physically removed contributing the reduction of the parasite 
loads without all parasite elimination. Freezing time and temperature recommendations for fish intended to be eaten raw or lightly cooked are different in jurisdictions, for examples, Canada recommends $-20^{\circ} \mathrm{C}$ for 7 days or below $-35^{\circ} \mathrm{C}$ for 15 hours (in a blast freezer), The United States of America recommends $-35^{\circ} \mathrm{C}$ or below (in a blast freezer) until solid and hold at $-20^{\circ} \mathrm{C}$ or below for 24 hours, The United Kingdom recommends $-20^{\circ} \mathrm{C}$ for 7 days or $-35^{\circ}$ $\mathrm{C}$ or below for 15 hours, or previously frozen to $-18^{\circ} \mathrm{C}$ for at least 4 days for storage, transport and distribution purposes, and The European Commission recommends $-20^{\circ} \mathrm{C}$ or below for no less than 24 hours, or $-35^{\circ} \mathrm{C}$ or lower for no less than 15 hours for parasites (other than trematodes), and $-10^{\circ} \mathrm{C}$ for 5 days, or $-20^{\circ} \mathrm{C}$ for $3-4$ days, or $-28^{\circ} \mathrm{C}$ for 32 hours for trematodes metacercariae of Opisthorchis species and Clonorchis species. Treatment with anthelminthics (praziquantel : bithionol, paromomycin, or sodium amidotrizoate and meglumine amidotrizoate) can demonstrate around $95 \%$ of cure rate for treatment of these tapeworm parasites.

In conclusion, the epidemiology of Diphyllobothriasis nikonkaiense has drastically changed from rural to urban areas due to rapid expansion of transportation system for fresh and frozen fish to meet a demand for seafood including raw salmon in healthy diets. Freezing and storing at $-20^{\circ} \mathrm{C}$ for 7 days or $-35^{\circ} \mathrm{C}$ until solid and storing at $-35^{\circ} \mathrm{C}$ for 15 hours is sufficient to kill these tapeworm parasites, although these conditions may not be appropriate for freezing large fish that thicker than 6 inches.

\section{Assets from publication with us}

- Prompt Acknowledgement after receiving the article

- Thorough Double blinded peer review

- Rapid Publication

- Issue of Publication Certificate

- High visibility of your Published work

Website: https://www.actascientific.com/

Submit Article: https://www.actascientific.com/submission.php

Email us: editor@actascientific.com

Contact us: +919182824667

Citation: Attapon Cheepsattayakorn and Ruangrong Cheepsattayakorn. "Raw Salmon- and Seafood-Associated Infection". Acta Scientific Microbiology 3.3 (2020): 01-02. 